\title{
PERI-URBAN AND INFORMALITY IN TELUKNAGA, TANGERANG REGENCY, INDONESIA
}

\author{
Cipta Hadi $^{1 *}$, Evawani Ellisa ${ }^{1}$ \\ ${ }^{1}$ Department of Architecture, Faculty of Engineering, Universitas Indonesia, Depok 16424, Indonesia
}

(Received: February 2021 / Revised: March 2021 / Accepted: May 2021)

\begin{abstract}
'Desakota' has been acknowledged as a unique landscape condition in South East Asia and Indonesia especially. In the middle of emerging economies and rapid urban development, 'desakota' as a peri-urban area suffers environmental degradation in the economy and socioculture because of poor planning and control from state and local authority. Inequality, spatial segregation, and inadequate infrastructure or slums are issues that peri-urban'desakota' has to encounter. Nevertheless, as a tool for producing and adapting the built environment and introducing a spatial order, urban design shows less concern for developing this distinct periurban area. This study conducted in Teluknaga, Tangerang, the neighboring Jakarta, examined the significance of informality which shapes a compact urban form in the 'desakota' area. Data collection of the study was done through field study by conducting interviews, observations, and direct mapping. We conclude that the informality potents should be considered for designing 'desakota' to maintain its compact form and create a more sustainable urban form and a better urban life.
\end{abstract}

Keywords: Compact city; desakota; informality; kampong; peri-urban

\section{INTRODUCTION}

The term peri-urbanization refers to the formation of mixed spaces and also a process in which rural areas located on the outskirts of established cities transition are becoming more urban, physically as well as economically, and socially (Dupont, 2005; Webster, 2002). This periurban development process has begun since the Industrial Revolution and transformed into an escape for many people from the chaotic situation in the city center (Gallion \& Eisner, 1963). However, each country's peri-urbanization is highly contrasted between cities in developed and developing countries (Woltjer, 2014). In terms of spatial manifestation, peri-urbanization in the north is driven by suburban development called urban sprawl; meanwhile, in the south is known as 'desakota' (McGee, 1989), of which one of the characteristics is the urban-rural interplay. As a distinct landscape condition, 'desakota' still needs more concern from the urban design field's perspective.

Peri-urban areas in East Asia, which also refers to 'desakota,' particularly in Indonesia, suffer from problems such as uncontrolled and conflicting land uses conversion, spatial equity, or segregation, and inadequate infrastructure (Legates \& Hudalah, 2014). Despite the problems, the desakota also has some advantages, according to some studies. McGee, who consistently studies about 'desakota' had remarked some findings. Firstly, transition theory in cities in western countries is flawed.

*Corresponding author's email: ciptahad@gmail.com

DOI: https://doi.org/10.32783/csid-jid.v4i1.207 
Secondly, the coexistence of agriculture, industry, and other urban activities in the form of a mixed-use landscape offers the most viable option for preserving eco-systems within the EMR and producing a liveable and sustainable city region. East Asian countries should be developing their response to the rural-urban transformation (McGee, 2008). Aligns to McGee's study, Cairns argues that Asia's urban-rural regions may not necessarily suffer the same fate as European and North American cities enduring from urban sprawl patterns. Both McGee and Cairns agreed that this potential of 'desakota' requires new distinct approaches to urban planning and design.

It is estimated that the population of peri-urban areas in East Asia will increase by approximately 200 million people over the next twenty-five years, accounting for 40 percent of urban population growth in that region (Webster, 2002). According to Legates and Hudalah (2014), the peri-urban areas of developing East Asia are the epicenter of world urbanization. This epicenter contains a mix of formal estates and informal settlements, which refers to "kampung" or slums in Indonesia (McConville \& Wittgren, 2014). As Kusno argues that Kampung (in the city center or the case of this study "desakota" region) is a mediation place (placed in the middle) between city and village for immigrants from the village by offering an affordable life, so it is called 'Middling Urbanism' (Kusno, 2020b). Kampung cannot be separated from the formal city but has a strong relationship between space, economy and capital, and politics. The existence of the village is essential. Therefore, study about peri-urban 'desakota' is highly needed, aside from problems and the potentials that 'desakota' has.

Peri-urbanization faces the informality challenge as the industrial cluster development and other non-agricultural sectors are keep growing (Irawati et al., 2016). On the one hand, the growth of the informal sector also fulfilled the need of the people within the framework of Urban DMA (Dovey, 2016). In the typical fast-growing Indonesian cities of Depok, the informal development in Kelapa Dua district caused several urban spatial problems and degradations (Wasnadi \& Ellisa, 2019). We hypothesize that kampung as the informal settlement with the informal economic activities is a significant aspect to be considered for the development of the peri-urban area. Cozzolino et al. (2020) reviewed informality as identical to self-organization that should be intended as complementary rather than contradictory elements. The spontaneous spatial configurations may continuously emerge within intentionally created design frameworks. While, both McGee and Cairns had emphasized more on mixed land use and the potential of food production that peri-urban areas possess, the informality which becomes daily facts and natural challenge for the peri-urban condition is less concerned. Therefore, this study aims to examine the significance of informality in the 'desakota' area regarding how it affects the urban form and future development.

The study is conducted in a district located in the area adjacent to the megapolitan Jabodetabek, namely Tangerang Regency. Tangerang Regency is a district located on the west and north side of Kota Tangerang and DKI Jakarta. With an area of $959.60 \mathrm{~km} 2$, Tangerang district has 29 districts. Like most districts, the area of the Tangerang Regency is reasonably large. As a result, some districts (kecamatan) are located very far from the center of their Tangerang regency (kabupaten) which is the center of activity for administration and economic activities. As the center, Tangerang city receives more attention for development. In most sub-districts, land use is dominated by green land uses, particularly agriculture. On the south side, several Tangerang district parts are the new towns rapidly developed by major developers in Indonesia, namely Lippo Karawaci and BSD City. In addition, the development of industrial estates with various scales that are not well controlled and planned is also spread in almost all parts of the Tangerang Regency. This development results in the "desakota" patterns characterized by a mix of agricultural, residential, industrial, and commercial areas. 


\section{LITERATURE REVIEW}

\subsection{Peri-urbanisation and Urban Design}

The word peri-urban describes the interface between rural and urban activities and embodies a transition from rural to urban norms, legislation, and institutional settings, in which social structures, commercial activities, and even the built environment are in flux (McConville \& Wittgren, 2014). McConville's definition of peri-urban about transition and physical changes aligns with Dupont's (2005). 'Peri urban' is an area outside existing urban agglomeration where large changes occur over space and time (Dupont, 2005). This transformation and change of peri-urban began from the industrial revolution era due to the congestion in the city center. Later, some scholars regard this transformation of peri-urban as "peri-urbanization" (Dupont, 2005; Webster, 2002). The term peri-urbanization refers to the formation of mixed spaces and a process in which rural areas located on the outskirts of established cities transition more urban in physical, economic, and social (Dupont, 2005; Webster, 2002). Peri-urbanization, which occurs in suburban development, led to urban sprawl patterns like in European and North American cities.

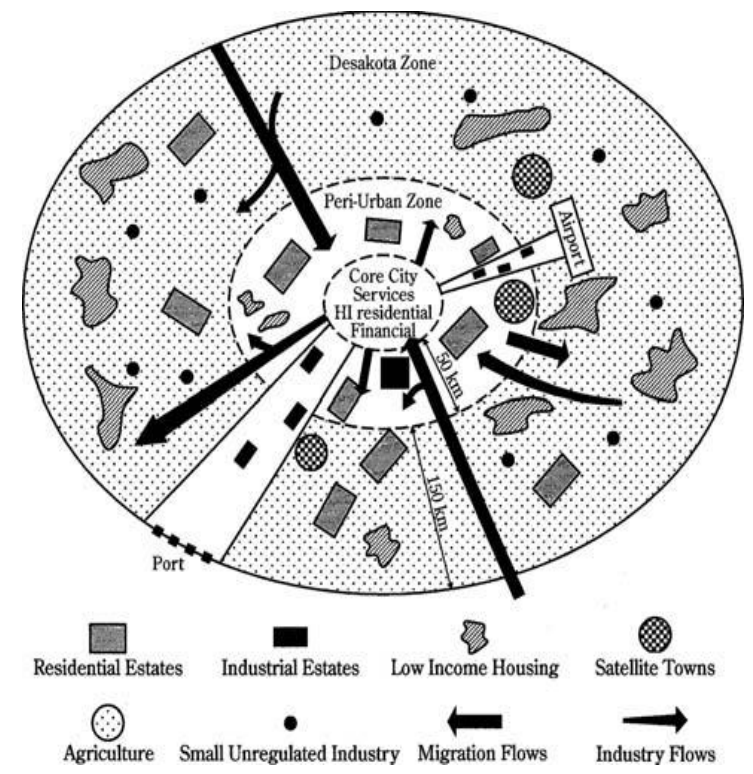

Figure 1 Configuration of mega-urban in Asia

Source: (McGee, 2008)

On the other hand, the phenomenon of the global south peri-urban occurs differently. The transformation phenomenon is known as 'desakota,' introduced by Terry McGee (1989). This phenomenon is caused by the fragmented growth of the industrial sector in the city's outskirts, which is still rural. Spatially, this transformation results in mixed of land use, between agriculture and industry. Besides, the socio-economic impact that occurs is a shift in the economic sector from agriculture to industry, trade, and services and an increase in the participation of women as workers (McGee, 1989). McGee (2008) also identified the type of spatial configuration in big cities (mega-urban) in Asia (see Figure 1). With these different patterns of transformation, discourses regarding peri-urban development in Asia have begun to emerge. As he continued his study of "desakota" in East Asia, McGee argues that the concepts of urban transition and transformation are not the same in each city. The urban-rural in East Asia must go through the transitions that European and North American cities do to develop.

To manage the spatial transformation of "desakota," urban design and designer are required to come into play. Urban design plays a role in addressing the uncontrolled and fragmented landuse development as one of the main features of urban design by introducing a spatial order 
based on a certain principle (Cozzolino et al., 2020). Some studies from urban design fields have been conducted which proposed a spatial order. Some of these studies will be discussed in the following paragraph.

According to Cairns et al. (2017), urban-rural area (peri-urban 'desakota') is a pathway to a distinctive, sustainable urban development by integrating high dense populations, diverse land uses, robust economies, rich natural ecologies, and vital sites of food production. Aligns with McGee (2008) about urban-rural transition, Cairns argues that urban-rural regions in Asia's urban-rural regions may not necessarily suffer the same fate as the urban sprawl in Europe and North American cities. He stated that it threatens cities' functional diversity, environmental sustainability, and, by encroaching on fertile agricultural land, it is a resilient approach to food production. Specifically Indonesia, he argues that Indonesia currently experiences an increasing agricultural land conversion due to a lack of control and inability to successfully enforce the land development and spatial planning policies and regulations from the local government (Stephen Cairns et al., 2017).

Cairns proposes an idea about developing an urban-rural area in Indonesia. The idea is called 'tropical town' (Urban-Rural Systems, n.d.). A 'tropical town' is a design area in the form of a small town with local food production and other facilities that support the self-sufficient city. He has started this idea by building a prototype of "Expandable House" in Batam, Kepulauan Riau, Indonesia. This idea responds to a unique urban-rural condition of Indonesia and rooted in the incrementality of the Indonesian houses' vernacular architecture.

A Singaporeans architect, Tay Kheng Soon, also offers opinions and ideas regarding the periurban development model. He is explicitly stated in his proposition "Rubanisation" (Tay, 2013)that the "desakota" phenomenon by McGee (1989) is nothing but the failure of a regional development model. As a critic of urban and rural dichotomy and capitalistic of a city system, he proposed an idea named 'Rubanisation.' "Rubanisation" is a fusion between rural and urban form, which McGee also means about the idea of managing rural-urban in East Asia. The idea of "rubanization" also aligns with the previous idea, namely Agricultural City by Kurokawa (1977). Kurokawa proposed an idea named Agricultural City, which is a combination between a city (with its urban characteristic) and a village (with its rural characteristic). A village could also be a city, or in other words, urban and rural are blended in one region.

As a conclusion of this review, we know that urban design as an organizer of spatial order needs to address the "desakota" issues. Thus, those mentioned studies also show the urgency of the urban design field to observe it further. The urgent study regards the statement of McGee (2008) and Cairns (2017) about the need for a distinct planning and design approach, aims to find an appropriate approach to address the issue of spatial order and production and adaptation of the built environment of the desakota region.

\subsection{The informality of Peri-urbanisation and Urban Design}

Urban informality can emerge in two forms: informal practice (hawkers, illegal parking, etc.) and informal settlement (Dovey, 2012). There are three informal settlement typologies based on the processes of informal settlement growth, such as settling, inserting, and attaching (Dovey \& King, 2011). Settling is an unclaimed and often unbounded land as indigenous villages and towns have come about over millennia. Inserting is a process of inserting into the uninhabited, abandoned, or leftover fragments of urban space. Lastly, attaching is informal accretions or excrescences grow out of, or attach onto, the structures of the formal city.

Nevertheless, the three types potent to emerge in various cities. As far as the informal typologies are concerned, informal settlement growth processes are always related to the formal 
city. The peri-urban area contains a diverse mix of informal and formal settlements or planned and unplanned settlements (McConville \& Wittgren, 2014). Thus, based on this classification, the informal settlement in the "desakota" region emerge in settling type.

Urban informality is also recognized by the term "urban messiness" (Chalana \& Hou, 2016). "Messiness" denotes urban conditions and processes that do not follow institutionalized or culturally prescribed notions of order. It suggests an alternative structure and hierarchy and agency and actions that are often subjugated by the dominant hierarchy, including notions of spatial and visual orders as well as social and political institutions and cultural norms. Amid the development of discourse in urban planning, such as the Garden City movement (Ebenezer Howard), the City Beautiful movement, and the Modernism movement (such as Le Corbusier), informality is considered a city disease. Hence, it is something that must be eliminated (Chalana \& Hou, 2016). Urban informality is defined as a city condition lacking formal control, planning, and construction, but it does not necessarily mean a slum area or a squatter (Dovey \& King, 2011). Kusno (2016) also argues that informality, if it is viewed from the vision of an order, is a condition that is uncontrollable, irregular, even anarchist, which can be overcome by modernization.

Another study asserts that informality or "kampung" (not only in the inner city but also in the outskirt of the city) and formal city form a reciprocal relationship yet not equal (Kusno, 2020b). The author relates the position of the "kampung" to capital, which supplies laborers to the formal business and capitalist economy. In his public lecture, he extended his opinion whether "kampung Kota" and also "desakota" is a transitional space or an exceptional space that is suppositionally changed into permanent (Kusno, 2020a).

Informality and peri-urban condition somehow has a similar description. For instance, informality implies a lack of formal control over planning, design, and construction (Dovey, 2012). Meanwhile, peri-urbanization also describes a mixture of planned and unplanned settlements, inadequate service infrastructures, insecure land tenure, social tension, and environmental and health problems (Legates \& Hudalah, 2014; McConville \& Wittgren, 2014). Therefore, it can be said that informality is the nature or peri-urban or "desakota" region. Thus, this study considers "kampung" in the "desakota" region as an exceptional and permanent space as observed from the role and multidimensional interconnection within the city.

\section{RESEARCH METHODS}

Our study aimed to reveal the question of whether the "desakota" area potents to perform the characteristics and requirements of a compact city. To answer the research question, we tried to undertake the field survey to understand how the residents of informal settlements adopted the informal daily practice in conjunction with the formal development of the public places and facilities. We try to analyze the possibility of Teluknaga becoming a compact city based on three core aspects in defining the compact city's idea: 1) density, 2) mix used, and 3) accessibility.

This research was conducted using a combination of observational surveys and in-depth interviews. Guiding by the google-map, we conducted the initial survey by slowly walking down the areas of Teluk Naga district to confirm the situation depicted on the maps and experiencing the spaces before mapping all attributes and situations indicated the density, the building functions, and the accessibility. We conducted in-depth interviews with 10 (tens) respondents of residents who lived in the kampung near the district center with different backgrounds (and mixed-income). The residents who have been long enough in the kampung were deliberately chosen as respondents for their ability to understand their habitation. For 
example, to understand the land ownership of informal settlements, we asked their dwelling histories through asking how they occupied the land, built and resided in their shelters. To understand how they dealing with the scarcity of resources, we asked how they get electricity, drink water, and other needs in everyday life. We also asked their experience of mobility through asking whether they do travel to the center city of Tangerang (which is 12 Kilometers away from Teluk Naga) or not and why. To understand their connection to the district center of the peri-urban area, we asked their view and perception of Teluk Naga center in relation to their daily needs and expectation.

Mapping is conducted by combining direct mapping and google maps. The mappings are land use, formal and informal public transportation line and spot, and identification of ongoing and future development of the surrounding area. We referred to Kim Dovey: "The aim is not to produce a facsimile of the city nor an image to be replicated but to spatially expose the abstract set of forces that produces and sustains the city for better or worse. These forces may be political, material, aesthetic, social, economic, or environmental” (Dovey \& Ristic, 2017).

\section{RESULT AND DISCUSSION}

\subsection{Peri-urbanisation in Teluknaga, Tangerang Regency}

One of the sub-districts in the Tangerang Regency, which is become our case study, is Teluknaga. Geographically, Teluknaga is located on the northern coast of Tangerang. Teluknaga is district (kecamatan) with some sub-districts (kelurahan). It has $40.58 \mathrm{~km} 2$ with a population density of 3300 people/ $\mathrm{km} 2$ and consists of 13 sub-districts (kelurahan and desa). Geographically, Teluknaga District is far from the center of the Tangerang Regency government. However, Teluknaga District is closer to Kota Tangerang and DKI Jakarta. The area is also adjacent to the International airport of Soekarno Hatta.

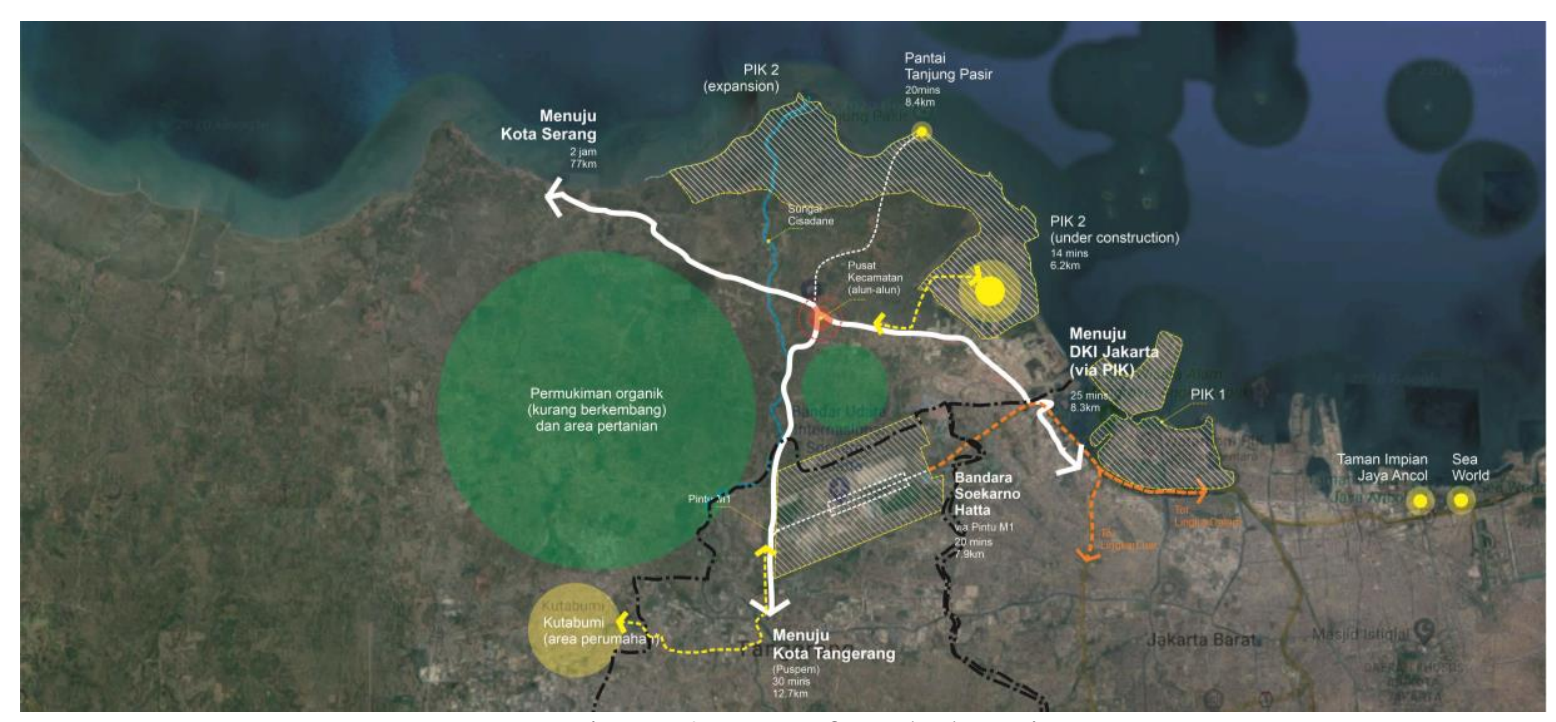

Figure 2 Map of study location

Source: Survey by the author using the map adopted from google map 
According to BPS data for 2019, four urban villages are holding the status of the urban category, namely Kampung Melayu Barat and Timur, Pangkalan, and Kampung Besar, while the rest are still in the rural category. Two of the four kelurahan have the highest population density in Teluknaga District. More specifically, the location of this study is the center of the sub-district of kelurahan Kampung Melayu Barat and Timur, where the square, sub-district office, police station, health center, and the subdistrict's grand mosque are located.

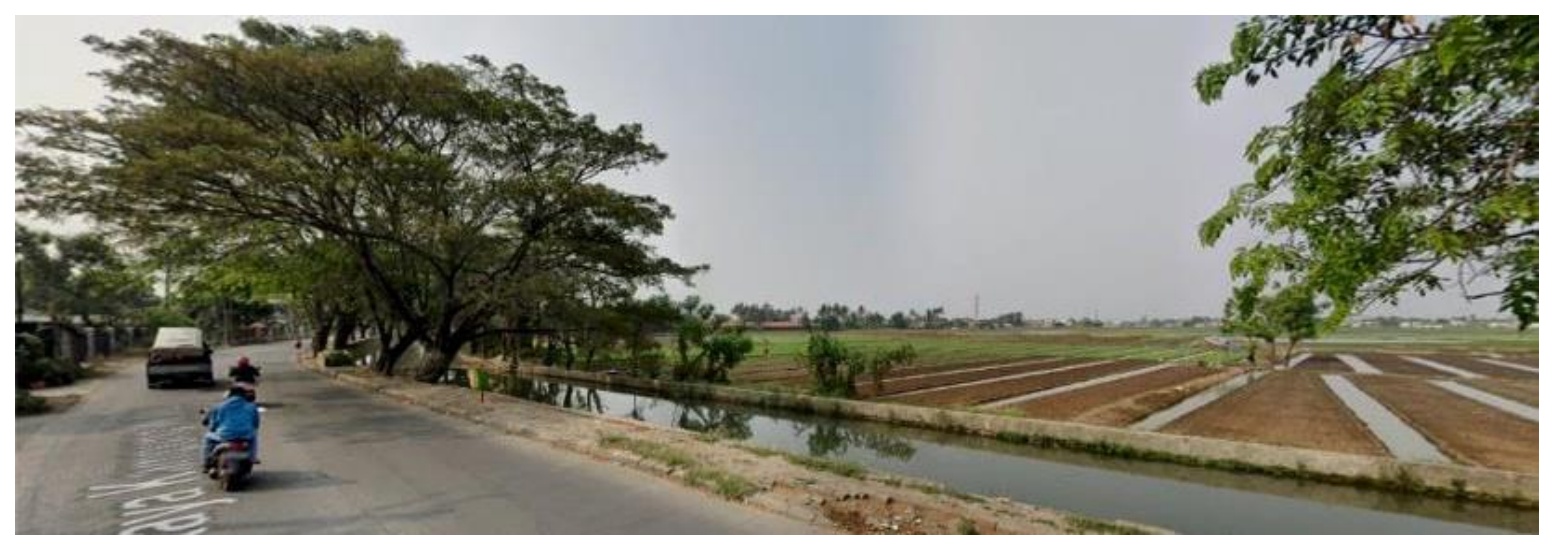

Figure 3 View of agricultural land in desakota region of Teluknaga Source: Google Street Map

Analysis through mapping revealed that the existing conditions around the central area of the Teluknaga sub-district are undergoing some significant developments. On the west and east sides of the four "kelurahan" that are the industrial areas are developing rapidly. The transformation could be seen in the map over the last 15 years, where significant growth can only be visible in the industrial sector. Meanwhile, on the north side of the sub-district center, there have been extensive housing and urban infrastructures, such as the development of Pantai Indah Kapuk 2 and the JORR 2 toll road.

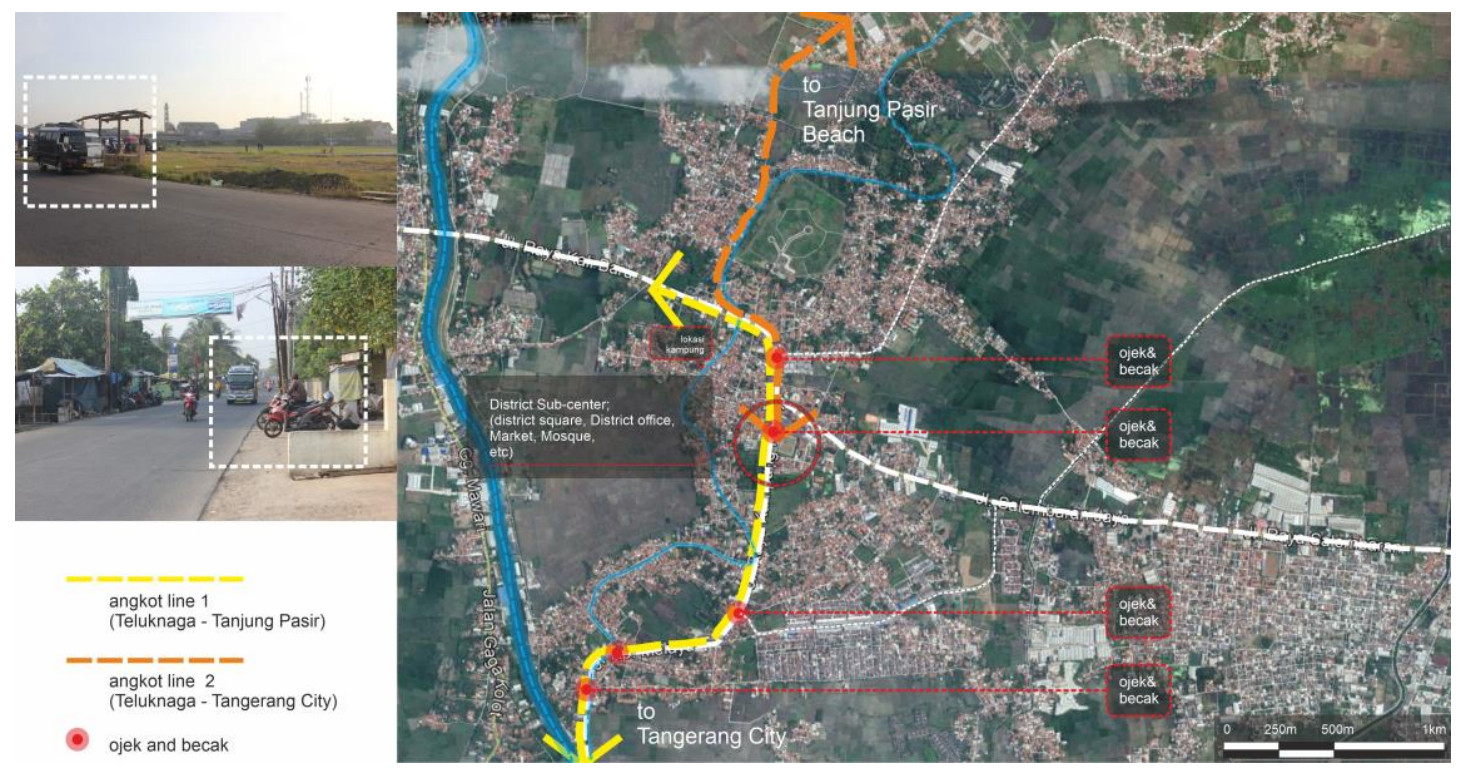

Figure 4 Accessibility in Teluknaga

Source: Survey by the author using the map adopted form google map

In terms of accessibility, this district sub-center area only has two types of formal public transportation. First, public transportation to and from Tangerang City of large "angkot" 
(private paratransit minibus), headquartered in groups depending on the owner, for example, in the market parking lot, the square, or the front of a group of private houses. Second, public transportation of regular/small/white "angkot" heading to and from the Tanjung Pasir coastal area. Apart from these formal public transportations, there are informal and traditional public transportation, namely motorcycle taxis (gojek) and rickshaws (becak). Motorcycle taxis and rickshaws are scattered at several busy intersection points. The intersection point usually connects the main road (Jalan Raya Kampung Melayu) with small roads leading to residential areas.

\subsection{Land use and Informality Analysis}

The central area of the Teluknaga sub-district is relatively busy. Various building facilities and functions are scattered along the main road of Jalan Raya Kampung Melayu. Overall, all functions for the domestic requirements and daily activities of the residents have been fulfilled. Within the radius of 500 meters from the sub-district, there are main functions such as traditional markets, clinics (puskesmas), education facilities (SD of primary school, SMP or elementary school, and SMA or high school), and religious buildings (mosques, churches, and monasteries). Within a radius of one kilometer, located health facilities and city-level recreational services such as major hospitals and sports fields (football, futsal, etc.).

There is a public square in the center of this sub-district, facilitated with an open field, a running track, and a parking lot. However, this square is still relatively new, officially utilized by locals' residents in 2019, but in a condition that does not seem to be finished. This contemporary square was built following the relocation of the sub-district office (kantor kelurahan) at the (east) side of the square. Prior converted into the square, it was a poorly defined field known as the Tunas Jaya field. It was not fully open to the public since it was mainly utilized for formal ceremonies and education activities such as ceremonies, speech, student sports, camp, school performance, and other school activities.

The re-arrangement of the kelurahan office building complex affected the way the people utilize the new square. While the previous office arrangement and open space were rather conventional and poorly designed, the new composition of buildings and squares accommodated a more modern outlook. The new square represented the image of a typical plaza in other cities in Indonesia. In this square, both the activities and users are very diverse. This square is quite busy during the day and night. Residents enjoy various activities, ranging from women practice jogging and gymnastics, people of all ages relaxing/hanging out teenagers playing skateboarding, and other leisure activities. The activities and crowd of people trigger informal activities such as "angkot" parking and street vendors. The previous empty field with hardly any essential activities has been transformed into the square that has become one of the recreational destinations for Teluknaga residents. The square provides the residents a place for gathering and gives them a sense of belonging.

Another major feature in the Teluknaga area is the dense informal "kampung," as housing in the Teluknaga area is predominantly "kampung." According to the local people, Kampung at Teluknaga has been inhabited by at least three generations. However, as most of the inhabitants of the "kampung" in Teluknaga do not have strong land ownership, it is classified as an informal settlement. Some houses are semi-permanent buildings made from wooden structures. The kampung at Teluknaga has been grown organically without proper infrastructure. Administratively, several houses share one source for electrical supply, of which each house will pay the bill based on its electrical usage. A Group of tiny houses usually attached to a house that is bigger or more prosperous economically. Some households carry out ritual 
cleaning activities such as bathing, washing, and defecating communally in modest MCK (communal bath and toilet) located in the river.
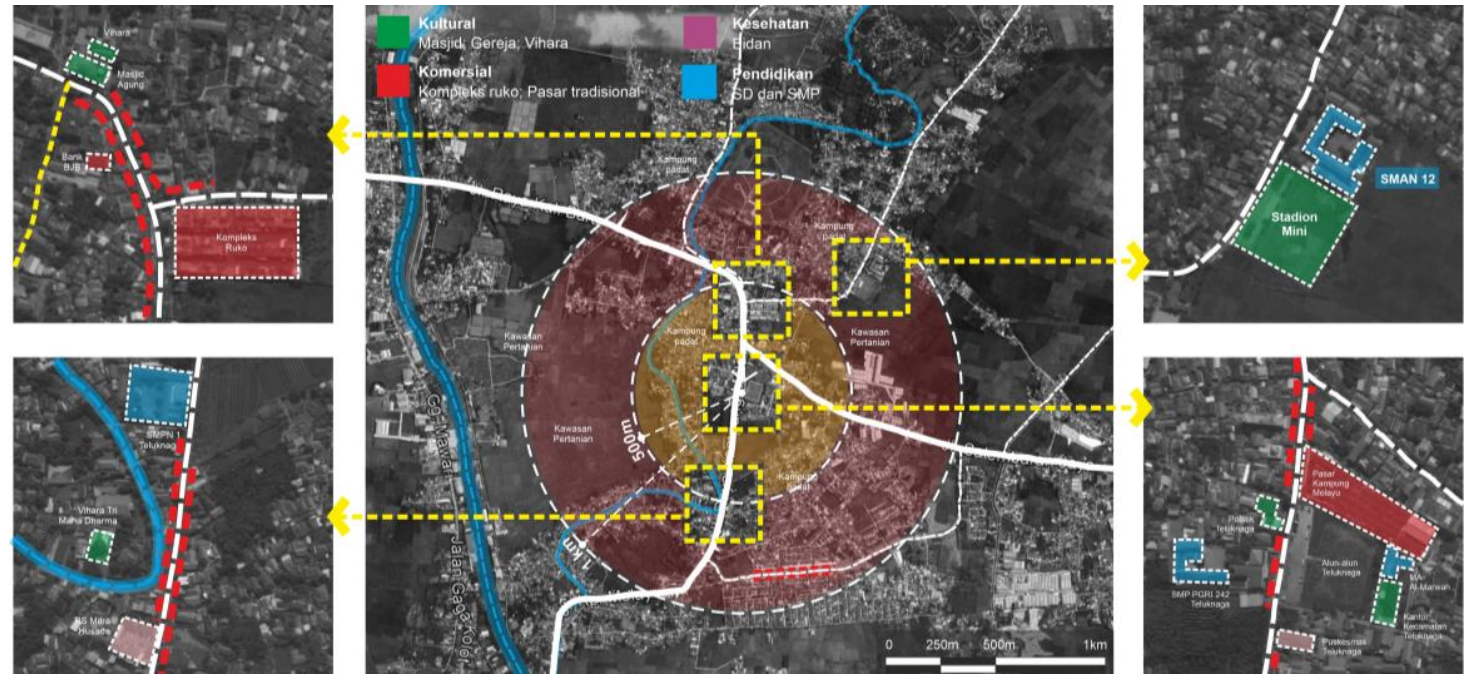

Figure 5 Land use analysis in $500 \mathrm{~m}$ and $1 \mathrm{~km}$ radius

Source: Survey by the author using the map adopted from google map

Based on the daily observations and semi-structured interviews with several residents, it is revealed that most of the residents of this kampung are the low-income group. Predominantly they are involved in the informal sector, such as hawkers, day laborers, or are employed in the local private or public sector. When we were asking about the place they have been traveled to so far, they said that they never been to the city center of Tangerang. It means that almost the whole time in their lives, they have never been traveled outside Teluknaga sub-district, even though Tangerang city is only 12 kilometers away from their homes because there is no necessity to do so. This "living locally" which is performed by kampung residents correlates with the spatial mapping that shows all the daily needs are met in 10-15 minutes of walking or cycling. It also corresponds with the residents' responses that they have no reason to travel to Tangerang inner city.

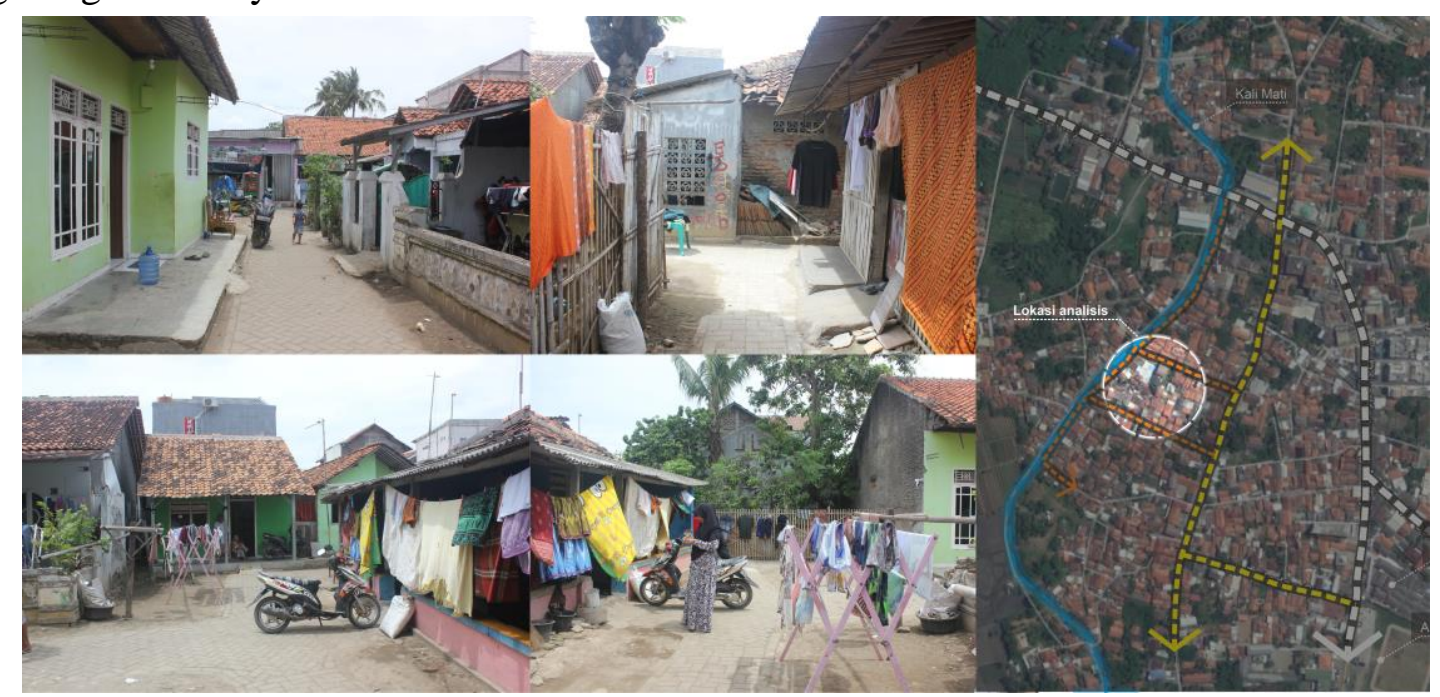




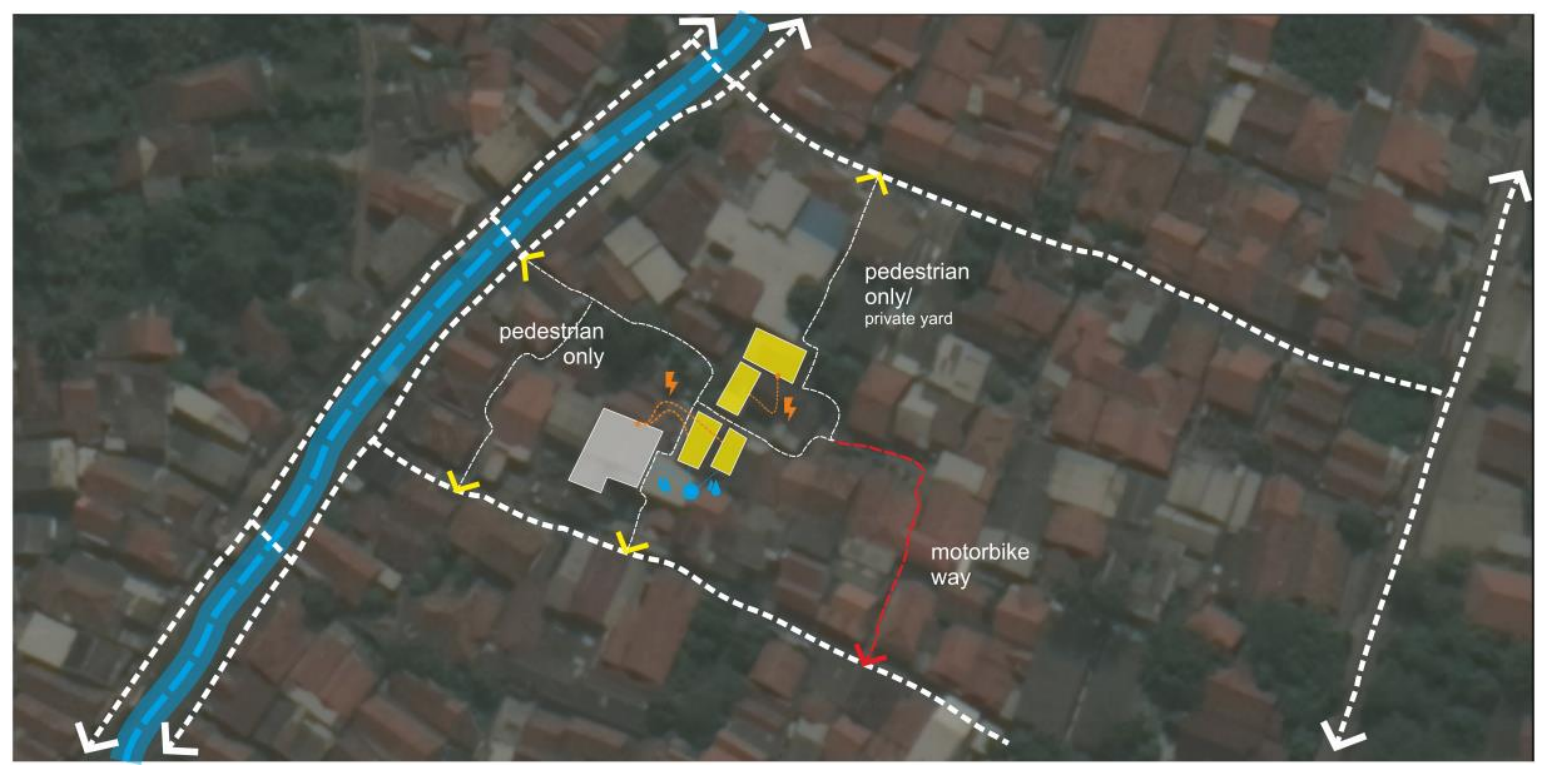

Figure 6 The condition of "kampung" in Teluknaga

Source: Survey by the author using the map adopted from google map

\subsection{Informality, Peri-urbanisation, and Compact City}

Hayashi (2003) states on the idea of 'compact city' as a form of urban regeneration. In his review, this idea was born against the background of shrinking cities' symptoms (decreasing population) experienced by cities in developed countries, including Japan. With the shift of industrial activity from the city center to the city's outskirts and the results of de-urbanization and suburbanization, the city center has become deserted due to the abandonment of its inhabitants. The key to the concept of a compact city is the intensification or concentration of density. Hayashi (2003) illustrated the compact city effect can reduce vehicle use (41\%) and air pollution (38\%) (the context of his study in Nagoya, Japan). The concept of a compact city indirectly makes humans an important aspect of a city, unlike industrial cities and the urban expansion that is car-oriented and industrialist or commercialist (Tay, 2013).

Dovey's intensification focuses on the concept of Urban DMA (Dovey, 2016), namely density, mix, and access. This concept is rooted in Jacobs' (1961) theory of diversity but further developed. Density is a consideration of the closeness between people and their destination. The mixture is not only on functions, people, and activities; but also on living, working, and playing, even production, consumption, and transactions. Access is how places are connected through a road network or transportation (walking, cycling, or motorized vehicles). This DMA concept will then form an urban intensity to achieve a compact city and a high walkability city (allowing people to walk).

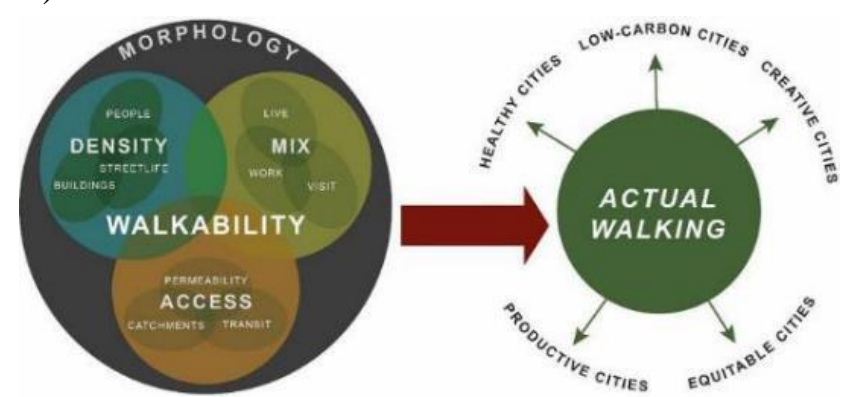

Figure 7 The diagram of the DMA concept by Kim Dovey

Source: (Dovey, 2016) 
Carlos Moreno, professor at the University of Paris 1 Pantheon-Sorbonne, proposed a concept of ' 15 minutes city' for Paris, France. It is a city where residents can reach all their daily needs (home, work, school, and other facilities) in just 15 minutes of cycling. Again, inspiration comes from Jane Jacobs's theory of proximity, which is the key in shaping the vitality of a city. He stated that the concept of a city with the mobility of commuters from the suburbs was outdated. The goal is not only in response to climate change and pollution from vehicles but also about improving human life quality (Peters, 2020). This idea has also been applied in other cities such as Melbourne, Ottawa, and Detroit (Reimer, 2020). This concept is nothing more than an implementation of the compact city principle. Compact city has dramatically influenced the planning of cities in the world.

Bibri et al. (2020) collected literature that discusses the sustainability benefits of a "compact city." There are three aspects of the benefits of a compact city, such as environmental, economic, and social. Each aspect has several points of benefit; for instance, on environmental aspects, the compact city can reduce the carbon footprint of the use of vehicles and energy, conservation of green space, and others. In the economic aspect, it can support local microbusinesses by increasing density, proximity, and fostering livelihoods for its residents. In the social aspect, it can improve the quality of social life of its inhabitants through social interaction, and access to green open spaces (Bibri et al., 2020).

The observation of the daily activities and the investigation on the spatial arrangement and spatial usage in this case study had revealed that Teluknaga districts sub-center fulfill the characteristics and requirements of a compact city form. Although most of the residents lived in the typical kampung and adopted an informal daily life practice, their living environment met the three aspects pre-requested of the idea of a compact city; density, mix, and access. Teluknaga sub-district demonstrated the potential and the possibility to develop as a compact city in 15 minutes.

\section{CONCLUSION}

Located in the peri-urban area of greater Jakarta, Teluknaga is still dominated by informal settlements. Although the formal, modern, and city-scale urban facilities rapidly developed in just a stone's throw away from Teluknaga, life in this sub-district is far from the hustle and bustle of the Jakarta megacity. However, at present, the improvement of public facilities and the infiltration of urban public life gradually shape a compact city form. Unlike the surrounding adjacent area, it is pervasive to see the local people of the Teluknaga area walk, cycle, and use traditional transportation such as becaks. Local people can also easily meet their daily needs such as food and entertainment, while productive activities such as work, schools, visit health services, and other essential activities are easily reached. However, unlike the compact city's idea in developed countries, informality becomes an additional element in forming a compact city. We assumed that Teluknaga reveals the new additional characteristic in defining the concept 'desakota' initiated by Terry Mc Gee.

This study contributes to the preliminary findings on the dialectical relationship between informality and the physical environment that is still a largely neglected issue in peri-urban studies. By focusing on informality, we need to consider the potential to focus on the rationality of everyday life rather than a grand scale of a dramatic transformation of peri-urban. We suggested the need to maintain the existing character of the compact city form of Teluknaga and consider the role of informality that makes it work. In this case, we are agreed with Chalana and Hou (2016) that if you want to understand urban life as a whole, you must understand informal life, which is sometimes hidden, vague, or under-appreciated, which also occurs in it. We have to admit our limitation in this study to reveal the significance of informality in the formation 
concept of a compact city in the 'desakota' area. Therefore, further studies are needed to find the spatial formation processes that emerge as the consequence of informal "kampung" activities and informal economic activities. Thus, informality should be considered as one of the important factors to define the 'desakota' area toward the sustainable city form and better future.

\section{ACKNOWLEDGEMENT}

This research is funded by Excellence Basic Research of Higher Education or Penelitian Dasar Unggulan Perguruan Tinggi (PDUPT) Number: 8/AMD/E1/KP.PTNBH/2020 ( $2^{\text {nd }}$ Year).

\section{REFERENCES}

Bibri, S. E., Krogstie, J., \& Kärrholm, M. (2020). Compact city planning and development: Emerging practices and strategies for achieving the goals of sustainability. Developments in the Built Environment, 4. https://doi.org/10.1016/j.dibe.2020.100021

Cairns, Stephen, Ting, C., Irawati, M., \& Lee, J. (2017). Urban-Rural Systems in Monsoon Asia. In S. Cairns \& D. Tunas (Eds.), Future Cities Laboratory; Indicia 01 (pp. 183-190). Lars Müller Publishers.

Chalana, M., \& Hou, J. (2016). Messy Urbanism: Understanding the "Other" Cities of Asia. Hong Kong University Press. https://hkupress.hku.hk/pro/344.php

Cozzolino, S., Polívka, J., Fox-Kämper, R., Reimer, M., \& Kummel, O. (2020). What is urban design? A proposal for a common understanding. Journal of Urban Design, 25(1). https://doi.org/10.1080/13574809.2019.1705776

Dovey, K. (2012). Informal urbanism and complex adaptive assemblage. International Development Planning Review, 34(4). https://doi.org/10.3828/idpr.2012.23

Dovey, K. (2016). Urban Design Thinking: A Conceptual Toolkit: (1st ed.). Bloomsbury Academic. https://www.bloomsbury.com/uk/urban-design-thinking-9781472566959/

Dovey, K., \& King, R. (2011). Forms of informality: Morphology and visibility of informal settlements. Built Environment, 37(1). https://doi.org/10.2148/benv.37.1.11

Dovey, K., \& Ristic, M. (2017). Mapping urban assemblages: the production of spatial knowledge. Journal of Urbanism, 10(1). https://doi.org/10.1080/17549175.2015.1112298

Dupont, V. (2005). Peri-urban dynamics: population, habitat and environment on the peripheries of large Indian metropolises : a review of concepts and general issues.

Gallion, A., \& Eisner, S. (1963). The Urban Pattern: City Planning and Design (2nd Edition). Van Nostrand. https://www.amazon.com/Urban-Pattern-City-PlanningDesign/dp/B0000CLYUP

Hayashi, Y. (2003). Compact city as a means of long-term urban regeneration. In International Journal of Urban Sciences (Vol. $7, \quad$ Issue 2). https://doi.org/10.1080/12265934.2003.9693531

Irawati, M., Cairns, S., \& Suryadjaja, R. (2016). The Livelihood Impacts of the Large-scale Industrial Estate in Emerging Peri-urban of Jakarta. LANDAC International Conference, 12 13.

Kurokawa, K. (1977). Agricultural City. In Metabolism in Architecture (pp. 46-47). Westview Press.

Kusno, A. (2016). The Order of Messiness: Notes from an Indonesian City. In C. Manish \& J. Hou (Eds.), Messy Urbanism: Understanding the "Other" Cities of Asia (pp. 46-60). Hong Kong University Press.

Kusno, A. (2020a). “Kota Tengah”. Virtual Public Lecture Series. Institut Teknologi Sepuluh Nopember (ITS). https://youtu.be/O_d6mblUHII

Kusno, A. (2020b). Middling urbanism: the megacity and the kampung. Urban Geography, 41(7). https://doi.org/10.1080/02723638.2019.1688535 
Legates, R., \& Hudalah, D. (2014). Peri-urban planning for developing east asia: Learning from chengdu, china and yogyakarta/kartamantul, indonesia. Journal of Urban Affairs, 36(S1). https://doi.org/10.1111/juaf.12106

McConville, J., \& Wittgren, H. B. (2014). Peri-Urban Sanitation and Water Service Provision: Challenges and opportunities for developing countries. https://mediamanager.sei.org/documents/Publications/SEI-ProjectReport-EkaneSanwatPua.pdf

McGee, T. G. (1989). Urbanisasi or kotadesasi? Evolving patterns of urbanization in Asia. Urbanization in Asia.

McGee, T. G. (2008). Managing the rural - Urban transformation in East Asia in the 21st century. Sustainability Science, 3(1). https://doi.org/10.1007/s11625-007-0040-y

Peters, A. (2020). Paris's mayor, Anne Hidalgo, wants to build a "15-minute city." https://www.fastcompany.com/90456312/pariss-mayor-has-a-dream-for-a-15-minute-city

Reimer, J. (2020, March 24). The 15-minute infrastructure trend that could change public transit as we know it. https://360.here.com/15-minute-cities-infrastructure

Tay, K. (2013). Rubanisation. In H. Mieg \& K. Töpfer (Eds.), Institutional and Social Innovation for Sustainable Urban Development (pp. 88-98). Routledge. https://www.routledge.com/Institutional-and-Social-Innovation-for-Sustainable-UrbanDevelopment/Mieg-Topfer/p/book/9781138780552\#

Urban-Rural Systems. (n.d.). "Tropical Town” . Retrieved May 16, 2021, from https://urs.sec.sg/category/tropical-town/

Wasnadi, H. F., \& Ellisa, E. (2019). Informality and Rapid Urban Transformation: Case Study of Kelapa Dua, Depok. IOP Conference Series: Earth and Environmental Science, 248(1), 012043. https://doi.org/10.1088/1755-1315/248/1/012043

Webster, D. (2002). On the Edge: Shaping the Future of Peri-urban East Asia. In Shorenstein APARC.

https://aparc.fsi.stanford.edu/publications/on_the_edge_shaping_the_future_of_periurban_ea st_asia

Woltjer, J. (2014). A Global Review on Peri-Urban Development and Planning. Jurnal Perencanaan Wilayah Dan Kota, 25(1). 